\section{Kustamonu Eğitim Dergisi Kastamonu Education Journal}

Mayıs 2019 Cilt:27 Sayı:3

kefdergi.kastamonu.edu.tr
Başvuru Tarihi/Received: 5.04.2018

Kabul Tarihi/Accepted: 19.05.2018

DOI: $10.24106 /$ kefdergi.2948

\title{
Ortaöğretim Beden Eğitimi Dersi Öğretim Programı Kazanımlarının Gerçekleşme Düzeyine İlişkin Mezunların Görüşleri
}

\section{Opinions of The Graduated Students on The Learning Outcomes of Secondary School Physical Education Curriculum}

\section{Öz}

\author{
Zekai PEHLEVAN ${ }^{1}$, Cenk TEMEL ${ }^{2}$, Murat KANGALGí ${ }^{3}$
}

Bu araştırmanın amacı; 2009-2017 yıllarında uygulanmış olan ortaöğretim beden eğitimi dersi öğretim programı kazanımlarının mezunların görüşleri yoluyla değerlendirilmesi ve beden eğitimi dersinin etkili ve verimli işlenmesine yönelik mezunların önerilerini belirlemektir. Tarama türündeki bu çalışmaya üç üniversitenin birinci sınıfinda ve farklı bölümlerinde okuyan toplam 1118 (Erkek \%33.0, Kadın \% 67.0) öğrenci katılmıştr. Veriler, "Lise Beden Eğitimi Dersi Öğretim Programı Değerlendirme Anketi" ile toplanmıştır. anket formu öğretim programının temel beceriler, değerler, hareket bilgi ve becerileri ile spor kültürü ve ulusal bilinç öğrenme alanlarını kapsayan kazanımlardan oluşturulmuştur. Verilerin analizinde betimsel istatistikler kullanılmıştı. Yapılan analizler sonucunda; ortaöğretim beden eğitimi öğretim programında alanlara göre belirlenen kazanımların çoğunlukla istendik düzeyde gerçekleşmediği, beklentilerin altında kaldığı katılımcılar tarafindan ifade edilmiştir. Gerçekleşme düzeyi en düşük "Spor Bilinci ve Organizasyonları" alt öğrenme alanı kazanımlarında olduğu gözlenmiştir.

Anahtar Kelimeler: beden eğitimi öğretim programı, program değerlendirme, ortaöğretim

\section{Abstract}

The purpose of this research is to evaluate the learning outcomes of secondary school physical education curriculum implemented in 2009-2017 through the opinions of the graduated students and to identify the suggestions of the graduated students for effective and productive teaching of physical education lessons. A total of 1118 (Men $33.0 \%$, Women $67.0 \%$ ) students from the first grade and different departments of three universities participated in this survey. The data were collected by "High School Physical Education Curriculum Evaluation Survey". The survey form was based on the achievements including the fields of basic skills, values, movement skills and knowledge as well as sports culture and national consciousness learning. Descriptive statistics were used in the analysis of the data. As a result of the analysis, participants stated that the achievements determined according to the fields in the secondary education physical education curriculum were not performed at a desired level and fell short of the expectations. It was observed that the lowest level of achievement was in "Sports Consciousness and Organizations" sub-learning field.

Keywords: physical education curriculum, curriculum evaluation, secondary education,

1. Mersin Üniversitesi, Spor Yüksekokulu, Beden Eğitimi Öğretmenlik Bölümü, Mersin, Türkiye.;https://orcid.org/0000-0003-4532-2508

2. İnönü Üniversitesi, Spor Bilimleri Fakültesi, Beden Eğitimi ve Spor Öğretmenliği Bölümü, Malatya, Türkiye.; https://orcid.org/0000-0001-6777-085X

3. Cumhuriyet Üniversitesi, Beden Eğitimi ve Spor Yüksekokulu, Beden Eğitimi ve Spor Öğretmenliği Bölümü, Sivas, Türkiye.; https://orcid.org/0000-0002-7480-199X Atıf / Citation: Pehlevan, Z., Temel, C., Kangalgil, M. (2019). Ortaöğretim Beden Eğitimi Dersi Öğretim Programı Kazanımlarının Gerçekleşme Düzeyine Ilişkin Mezunların Görüşleri. Kastamonu Education Journal, 27(3), 1209-1222. doi:10.24106/kefdergi. 


\section{Extended Summary}

Nowadays, societies need manpower that can keep up with the rapid development and change in science and technology. Education plays a crucial role in the training of the qualified human resources to become an information society (Yüksel \& Sağlam, 2014, p. 3). An education curriculum is vitally important for not only the school itself but also the mental and physical health of a society (Ornstein \& Hunkins, 1998, p. 1). Therefore, education programs have an important function in a qualified education. Changes in the needs and expectation of a society requires revaluation and improvement of the education curriculum (Saylor, Alexander \& Lewis, 1981). Besides, the need to identify the realization level of the achievements specified for curriculums, and determine and improve the strengths and weaknesses of the lesson plans require a curriculum evaluation (Tyler, 1967, p. 69; Ertürk, 1979; Popham, 1993; Oliva, 2001). Thus, the purpose of this study is to identify the opinions of the graduated about the learning outcomes of secondary school physical education curriculum implemented in 2009-2017 and their suggestions for an efficient and productive physical education lesson.

The sample group of this study is composed of a total 1118 students (men 33.0\%, women 67.0\%) who enrolled in the first grade and different departments of three universities (Mersin, Inonu and Cumhuriyet). The mean age of participants is $M=19.66$, ( $S D=1.25)$. "High School Physical Education Curriculum Evaluation Survey" was used to collect data. The survey items were prepared based on the achievements including the basic skills and values of secondary school PE curriculum, general and specific movement knowledge and skills, personal development, the sub-learning fields of sports culture and organizations. The answers to the survey were "Yes", "Partially" and "No". Additionally, a semi-structured open-ended question about more effective and efficient teaching of PE lessons was also addressed to the participants. Frequency distribution ( $f$ ) and percentage values (\%) were used in the analysis of the obtained data.

The result of the analysis showed that "Ability to use IT technologies" (43.9\%), "Ability to research" (43.6\%) and "Ability to correct, efficient and fine use of Turkish language" (43.5\%) occurred at the lowest level among the PE curriculum basic skills. Among the achievements about "values" of the curriculum, "Patriotism" (25\%), "Sense of aesthetic" (24.8\%) and "Gentlemen behavior" (23.7\%) were found to occur at the lowest rate. "Ability to develop self-expression skills through play and drama" (39.7\%) in the field of general movement knowledge and skill learning in PE curriculum; "Ability to recognize universal cultural values by participating in the related activities including music, dance and traditional games of any sports branch" (38\%) in the sub-learning field of special movement knowledge and skills; "Participate in periodic tests to learn about physical development" $(47.4 \%)$ in the sub-learning field of personal development and healthy life were found to occur at the lowest level. It was also observed that "Ability to understand Olympism philosophy" (46.4\%) in the sports consciousness and organizations sub-learning field of PE curriculum was the achievement occurred at the lowest level. The graduates highly suggested that the gym, equipment and material needs should be fulfilled, the understanding of "give them a ball and just let them play!" should be abandoned, the content of the lessons should be diversified, physical education teachers should value the interests and desires of students, there should be more extra-curriculum sports organizations and the participation in sports branches should be encouraged, there should be no idle class, the need for more PE teachers should be satisfied and weekly lesson hours should be increased.

As a result, it is ideal to achieve $100 \%$ of the objectives of a curriculum, however this level of realization is generally unattainable. Therefore, not only the effectiveness of the program should be assessed but also all the system components (objectives, content, teaching-learning process, assessment and evaluation) should be individually analyzed and assessed (Erden, 1993, p. 15). The conditions of the schools considerably determine who can learn and who cannot learn at school. In other words, the quality of teaching services provided for students plays an important role in this regard (Bloom, 1976-2012, p.139). From this point of view, it can be stated that the achievement levels of learning outcomes identified in the curriculum mostly do not meet Bloom's "mastery learning" criteria (75-85\%) and the achievements of sub-learning field "Sports Consciousness and Organizations" happened to occur at the lowest level. 


\section{Giriş}

Günümüzde toplumlar; bilim ve teknolojideki hızlı gelişme ve değişime uyum sağlayabilecek insan gücüne ihtiyaç duymaktadırlar. Eğitim, Toplumların, bilgi toplumu olma yönünde nitelikli insan gücü yaratmada önemli bir görev üstlenmektedir (Yüksel ve Sağlam, 2014, s. 3). Diğer yandan, ortaya çıkan sorunlar ve ihtiyaçlar da her on yılda farklılaşabilmekte ve daha karmaşık bir durum almaktadır (Fitzpatrick, Sanders \& Worthen, 2004, s. 3). Bu ve benzer problemlerle başa çıkmak ve toplumların refahını artırmada etkili olacağı varsayımıyla eğitim programları hazırlanmakta ve sürekli olarak da geliştirilmektedir. Çünkü bir eğitim programı, sadece okulun değil, bütün bir toplumun ruh ve beden sağlığı için yaşamsal öneme sahiptir (Ornstein ve Hunkins, 1998, s. 1). Bir eğitim programı tasarısı bireyin (çocuğun), ilgili alanın ve toplumun ihtiyaç ve beklentilerini karşılayabilecek nitelikte hazırlanması genel kabul görmüş temel bir ilkedir (Tyler, 1967; Ertürk, 1986; Varış, 1988; Henson, 1995; Oliva, 2001; Fitzpatrick, Sanders \& Worthen, 2004). Dolayısıyla, ihtiyaçların ve beklentilerin değişmesi; eğitim programlarının yeniden değerlendirilmesini ve geliştirilmesini gerekli kılmaktadır (Saylor, Alexander \& Lewis, 1981; Henson, 1995; Gredler, 1996; McNeil, 1996; Fitzpatrick, Sanders \& Worthen, 2004).

Program değerlendirme; program geliştiriciler ve uygulayıcıların, bireylerin öğretim deneyimleri hakkında yargılarına ulaşmak için toplanan verilerin bir araya getirilmesi ihtiyacından doğmaktadır (Ornstein ve Hunkins, 1998, s. 319). Bununla birlikte, eğitim programlarında belirtilen kazanımların gerçekleşme düzeyini, derse ilişkin planların güçlü ve zayıf yanlarını belirleme ve geliştirme intiyacı da program değerlendirmeyi gerektirmektedir (Tyler, 1967, s. 69; Ertürk, 1979; Popham, 1993; Oliva, 2001). Çünkü, program değerlendirmenin amacı programın etkililiğini belirlemektir (Gredler, 1996; Stillwel \& Willgoose, 1997, s. 312;). Yine, program değerlendirme intiyacı; bireyler ve programın paydaşları olan kişi, kurum ve politika belirleyicilerin, programın etkililiği için kanıtlara sahip olmak; programın içeriğini, materyalleri ve kullanılan öğretim metotlarını değerlendirmek; öğrencilerin neler öğrendiğini ve hangi becerileri gösterdiklerini, yeni programın maliyetini ve bu maliyetin etkililiğini bilmek isterler (Ornstein ve Hunkins, 1998, s. 320). Bununla birlikte okullar, aileler ve toplum, eğitim programlarında belirlenen önemli hedeflerin erişi düzeyinin etkililiği konusunda değerlendirmeye ve bilgi sahibi olmaya intiyaç duyarlar. Aileler de çocuklarında ne tür bir değişim olduğuna bakarak, okula ve programa yönelik bir tutum geliştirirler (Tyler, 1967, s. 81). Program değerlendirmede toplanan veriler incelenerek; programın kabul edilmesine, değiştirilmesine veya kaldırılmasına karar verilir (Tyler, 1967, s. 80; Oliva, 2001, s. 438; Henson, 1995, s. 271; Ornstein ve Hunkins, 1998, s. 320). Eğitim programı için yapılan değerlendirme sonunda elde edilen kanıtlar doğrultusunda programın amaçları, içerik, öğretim durumları ve değerlendirme biçimi yeniden gözden geçirilip bir döngü halinde süreklilik kazanmaktadır (Tyler, 1967, s. 80; Fitzpatrick, Sanders \& Worthen, 2004). Programın amaçları doğrultusunda öğrenci davranışlarındaki değişimlerin test edilmesi, eğitim programı hakkında karar vermede kanıtlar elde edilmiş ve fikirler vermiş olur (Tyler, 1967, s. 74).

Program değerlendirme türü ise bu sürecin başarısında önemli rol oynar. Değerlendiricinin amacına bağlı olarak iyi bir program değerlendirmede hem biçimlendirici ve hem de sonuç/ürün değerlendirme kullanılır (Popham, 1993, s. 13; Fitzpatrick, Sanders \& Worthen, 2004; Yüksel ve Sağlam, 2014; Jewett, Bain \& Ennis, 1995, s. 314). Ancak, en etkili değerlendirme yaklaşımının "ürüne bakarak" değerlendirme olduğu ileri sürülmektedir (Ertürk, 1986, s. 116). Bu çalışmada toplam/ürün değerlendirme ve ölçüt olarak da 2009-2017 yıllarında uygulanmış olan Ortaöğretim Beden Eğitimi Dersi Öğretim Programının kazanımları referans alınmıştır. Çünkü çıktıların değerlendirilmesi, programın desteklenmesi veya uyarlamasına yönelik kararlara varılmak istenildiğinde kullanılmaktadır (Klenowski, 2010; akt. Şeker, 2014, s. 188).

Toplam/ürün değerlendirme; öğretim etkinliği tamamlandığında yapılır ve programın toplam sonuçlarının (çıktlar) değerlendirilmesini hedefler (Jewett, Bain \& Ennis, 1995, s. 314; Saylor, Alexander \& Lewis, 1981; Popham, 1993, s. 13). Toplam/ürün değerlendirmede öğrencinin yetişme seviyesi ile programın yetiştirme gücü hakkında bir değer biçmeye esas teşkil edecek verilerin elde edilmesi ve kullanılması söz konusudur. Ertürk'e (1986) göre, öğretim olup bittikten sonra, programa dönük kritik davranışların/çıktıların bir örneklemine göre yapılan değerlendirme daha anlamlı sonuçlar verebilmektedir (s. 113). Yine toplam/ürün değerlendirme, programın revize edilmesi gereken konuları hakkında da daha nesnel kanıtlar sunabilmektedir (Saylor, Alexander \& Lewis, 1981, s. 318). Toplam/ürün değerlendirmede, programdan mezun olanlarda kalıcı olan ve olmayan davranışların test edilerek, istendik davranış değişikliklerinin olup olmadığı hakkında karar verilir ve bu süreçte öz-değerlendirme ve kalem-kağıt testleri, kontrol listeleri ve envanterler uygun veri toplama yöntem ve araçları olarak görülmektedir (Tyler, 1967, s. 70; Stillwell, 1997, s. 312).

Bu araştırmaya konu olan Ortaöğretim Beden Eğitimi Dersi Öğretim Programı 2009-2017 yılları arasında uygulanmıştr. Milli eğitimin genel hedefleri doğrultusunda hazırlanan öğretim programının vizyonu; beden eğitiminin sosyal kalkınmadaki öneminden hareket ederek, beden eğitimi ve spor kültürüne sahip ve yarışma sporuna da temel oluşturacak yatay ve dikey hareketliliği sağlamak yoluyla, "öğrencileri; bedensel ve sportif etkinlikleri gerçekleştirmek için gereken 
bilgi ve becerileri edinmiş, bedensel olarak sağlıklı ve zinde, serbest zamanlarını verimli bir şekilde değerlendirmeyi bilen, öğrendiklerini kişisel gelişiminde ve yaşantısında olumlu olarak kullanan bireyler olarak görmektir" biçiminde belirlenmiştir (MEB, 2009, s. 1).

Bu vizyon doğrultusunda yapılandırmacı öğrenme yaklaşımıyla hazırlanan programının temel hedefi eleştirel düşünme, yaratıcı düşünme, problem çözme, karar verme; Türkçe'yi doğru, etkili ve güzel kullanma; araştırma, iletişim, bilgi teknolojilerini kullanma; öz yönetim, güvenlik ve korunma sağlama, girişimcilik gibi temel becerilerle birlikte dayanışma, hoşgörü, sevgi, saygı, vatanseverlik, estetik, barış, millî, manevi ve evrensel değerlere duyarlı olma, kişisel ve sosyal değerlere önem verme, sorumluluk ve centilmenlik gibi değerlerin kazandırılması hedeflenmektedir (MEB, 2009, s. 3).

Bu hedefler doğrultusunda beden eğitimi öğretim programı "Öğrenme Alanları (Hareket Bilgi ve Becerileri, Spor Kültürü ve Ulusal Bilinç) ve Alt Öğrenme Alanları (Genel Hareket Bilgi ve Becerileri ile Özel Hareket Bilgi ve Becerileri) biçiminde oluşturulmuş ve her bir alt öğrenme alanına ilişkin bilişsel, duyuşsal ve psikomotor kazanımlar belirlenmiştir (MEB, 2009, s. 5). Beden eğitimi öğretim programında belirlenen kazanımların değerlendirilmesine yönelik mezunların görüşlerinin belirlenmesi sınırlı bir program değerlendirme çalışması olarak düşünülebilir. Ancak programın temel beceriler, değerler ve programın temel ve alt öğrenme alanlarıyla ilgili kazanımlara yönelik sonuçlar; program geliştirme süreçlerine kanıtlar oluşturması açısından bu çalışmanın önemli olduğu düşünülmektedir. Buradan hareketle bu çalışmanın amacı; 2009-2017 yıllarında uygulanmış olan ortaöğretim beden eğitimi dersi öğretim programının kazanımlarının gerçekleşme düzeyine ilişkin mezunların görüşlerini ve beden eğitimi dersinin daha etkili ve verimli işlenmesine yönelik önerilerini belirlemektir.

\section{Yöntem}

Bu çalışma betimsel modelde tarama türünde bir araştırmadır. Örneklem grubunu, üç üniversitenin (Mersin, İnönü ve Cumhuriyet) birinci sınıfinda ve liseden mezun olduktan sonra en fazla iki yıl geçmiş farklı bölümlerde okuyan toplam 1118 (Erkek=\%33.0,

Kadın= \% 67.0) öğrenci oluşturmuştur. Katılanların yaş ortalaması $\bar{X} \bar{X}=19.66(1.25)^{\prime}$ 'dır. Katılanların demografik özelliklerine ilişkin ayrıntılı bilgiler Tablo 1'de verilmiştir. Veriler, araşttrmacılar tarafindan geliştirilen “Lise Beden Eğitimi Dersi Öğretim Programı Değerlendirme Anketi" ile toplanmıştır. Anket formunda yer alan maddeler 2009-2017 yılları arasında uygulanmış ortaöğretim beden eğitimi dersi öğretim programı temel beceriler, değerler, genel ve özel hareket bilgi ve becerileri, kişisel gelişim, spor kültürü ve organizasyonları alt öğrenme alanlarını kapsayan 9, 10, 11 ve 12. sınıf kazanımları esas alınarak hazırlanmıştır. Ankete cevaplar "Evet", "Kısmen" ve "Hayır" biçiminde verilmiştir. Ayrıca katılımcıların, beden eğitimi derslerinin daha nitelikli geçmesi ve belirlenen amaçlara ulaşması için önerilerini belirlemek amacıyla da yarı yapılandırılmış bir adet açık uçlu soru sorulmuştur. Elde edilen verilerin analizinde betimsel istatistiklerden frekans (f) dağılımı ve yüzdelik (\%) oranları kullanılmıştır. Açık uçlu soruya verilen yanıtlar ise içerik analizi yapılarak ana temalar ve alt temalar biçiminde verilmiştir.

Tablo 1. Katılanların demografik özellikleri

\begin{tabular}{|c|c|c|c|c|c|c|c|}
\hline Değişkenler & Alt Kategoriler & $f$ & $\%$ & Değişkenler & Alt Kategoriler & $f$ & $\%$ \\
\hline \multirow[t]{2}{*}{ Cinsiyet } & Kadın & 369 & 33.0 & \multirow{2}{*}{ Öğretmen durumu } & Var & 1038 & 92.8 \\
\hline & Erkek & 749 & 67.0 & & Yok & 80 & 7.2 \\
\hline \multirow[t]{3}{*}{ Üniversite } & Mersin & 418 & 37.4 & \multirow{3}{*}{ Dersi sevme durumu } & Seviyor & 828 & 74.2 \\
\hline & İnönü & 378 & 33.8 & & Çok az seviyor & 183 & 16.4 \\
\hline & Cumhuriyet & 322 & 28.8 & & Sevmiyor & 106 & 9.5 \\
\hline \multirow[t]{7}{*}{ Bölge } & İç Anadol & 192 & 17.2 & \multirow{4}{*}{$\begin{array}{l}\text { Öğretmenini sevme } \\
\text { durumu }\end{array}$} & Seviyor & 740 & 66.2 \\
\hline & Akdeniz & 412 & 36.9 & & Az seviyor & 228 & 20.4 \\
\hline & Marmara & 49 & 4.4 & & Sevmiyor & 150 & 13.4 \\
\hline & Karadeniz & 56 & 5.0 & & Erkek & 645 & 57.7 \\
\hline & D. Anadolu & 228 & 20.4 & \multirow[t]{2}{*}{ Öğretmen cinsiyeti } & Kadın & 232 & 20.8 \\
\hline & G. Doğu And. & 144 & 12.9 & & Değişti & 241 & 21.6 \\
\hline & Ege Bölgesi & 37. & 3.3 & \multirow{3}{*}{ Salon durumu } & Salon var & 583 & 52.1 \\
\hline \multirow{5}{*}{$\begin{array}{l}\text { Mezun olunan } \\
\text { okul türü }\end{array}$} & Genel Lise & 509 & 45.5 & & Salon yok & 535 & 47.9 \\
\hline & End.M.L. & 62 & 5.5 & & Katılmış & 479 & 42.8 \\
\hline & Meslek Lisesi & 213 & 19.1 & \multirow[t]{2}{*}{ Lisede spora katılım } & Çok az katılmış & 231 & 20.7 \\
\hline & İ.H.L Mezunu & 57 & 5.1 & & Katılmamış & 407 & 36.5 \\
\hline & Diğer Liseler & 277 & 24.8 & \multirow{3}{*}{$\begin{array}{l}\text { Üniversitede Sp. } \\
\text { katilım }\end{array}$} & Katilıyor & 337 & 30.1 \\
\hline \multirow[t]{2}{*}{ Mezuniyet } & Devlet okulu & 1040 & 93.0 & & Katilmıyor & 781 & 69.9 \\
\hline & Özel okul & 78 & 7.0 & & & & \\
\hline
\end{tabular}

|Kastamonu Eğitim Dergisi, 27(3), 2019| 


\section{Sonuçlar}

Tablo 2. Katılanların "Temel Beceriler” alanına ilişkin kazanımların gerçekleşme düzeyine yönelik görüşleri

\begin{tabular}{|c|c|c|c|c|c|c|}
\hline \multirow[t]{2}{*}{ Temel Beceriler $(\mathrm{N}=1118)$} & \multicolumn{2}{|c|}{ Evet } & \multicolumn{2}{|c|}{ Kısmen } & \multicolumn{2}{|c|}{ Hayır } \\
\hline & $\mathrm{f}$ & $\%$ & $f$ & $\%$ & $f$ & $\%$ \\
\hline Eleştirel düşünme becerisi & 527 & 47.1 & 191 & 17.1 & 400 & 35.8 \\
\hline Yaratıcı düşünme becerisi & 583 & 52.1 & 163 & 14.6 & 372 & 33.3 \\
\hline Problem çözme becerisi & 553 & 49.5 & 167 & 14.9 & 398 & 35.6 \\
\hline Karar verme becerisi & 577 & 51.6 & 204 & 18.2 & 337 & 30.1 \\
\hline Türkçeyi doğru, etkili ve güzel kullanma becerisi & 421 & 37.7 & 211 & 18.9 & 486 & 43.5 \\
\hline Araştırma yapma becerisi & 438 & 39.2 & 193 & 17.3 & 487 & 43.6 \\
\hline İletişim kurma becerisi & 670 & 59.9 & 152 & 13.6 & 296 & 26.5 \\
\hline Bilgi teknolojilerini kullanma becerisi & 414 & 37.0 & 213 & 19.1 & 491 & 43.9 \\
\hline Öz yönetim becerisi & 615 & 55.0 & 203 & 18.2 & 300 & 26.8 \\
\hline Güvenlik ve korunma sağlama becerisi & 607 & 54.3 & 190 & 17.0 & 321 & 28.7 \\
\hline Girişimcilik becerisi & 610 & 54.6 & 182 & 16.3 & 326 & 29.2 \\
\hline
\end{tabular}

Tablo 2'de lise mezunlarının beden eğitimi ve spor öğretim programında belirtilen temel becerilere ilişkin kazanımlardan en düşük oranla; \% 43.9'u "Bilgi teknolojilerini kullanma becerisi", \% 43.6'sı "Araşttrma yapma becerisi" ve \% 43.5'i de "Türkçeyi doğru, etkili ve güzel kullanma becerisi" kazanamadığını belirtmişlerdir. Temel becerilerden en yüksek oranla kazanıldığı belirtilen kazanımlar ise sırayla \% 59.9 oranıyla "iletişim kurma becerisi", \% 55 oranıyla "Öz-yönetim becerisi" ve \% 54.6 oranıyla da "Girişimcilik becerisi" olarak ifade edilmiştir.

Tablo 3. Katılanların “Değerler” alanına ilişkin kazanımların gerçekleşme düzeyine yönelik görüşleri

\begin{tabular}{lcccccc}
\hline Değerler (N= 1118) & \multicolumn{2}{c}{ Evet } & \multicolumn{2}{c}{ Kısmen } & \multicolumn{3}{c}{ Hayır } \\
\cline { 2 - 7 } & $\mathrm{f}$ & $\%$ & $\mathrm{f}$ & $\%$ & $\mathrm{f}$ & $\%$ \\
\hline Dayanışma içinde olma & 808 & 72.3 & 118 & 10.6 & 192 & 17.2 \\
Hoşgörü gösterme & 765 & 68.4 & 142 & 12.7 & 211 & 18.9 \\
Sevgi gösterme & 716 & 64.0 & 163 & 14.6 & 239 & 21.4 \\
Saygı duyma & 800 & 71.6 & 124 & 11.1 & 194 & 17.4 \\
Vatanseverlik & 669 & 59.8 & 169 & 15.1 & 280 & $\mathbf{2 5 . 0}$ \\
Estetik anlayış & 622 & 55.6 & 219 & 19.6 & 277 & $\mathbf{2 4 . 8}$ \\
Barış içinde olma & 722 & 64.6 & 165 & 14.8 & 231 & 20.7 \\
Millî, manevi ve evrensel değerlere duyarlı olma & 710 & 63.5 & 165 & 14.8 & 243 & 21.7 \\
Kişisel ve sosyal değerlere önem verme & 744 & 66.5 & 149 & 13.3 & 225 & 20.1 \\
Sorumluluk sahibi olma & 792 & 70.8 & 129 & 11.5 & 197 & 17.6 \\
Centilmence davranma & 703 & 62.9 & 150 & 13.4 & 265 & $\mathbf{2 3 . 7}$ \\
\hline
\end{tabular}

Tablo 3'de öğretim programının "Değerlere" ilişkin kazanımları incelendiğinde; en düşük düzeyde gerçekleştiği ifade edilen değerler \% 25 oranıyla "Vatanseverlik", \% 24.8 oranıyla "Estetik anlayış" ve \% 23.7 oranıyla da "Centilmence davranma" olduğu anlaşılmaktadır. Katılanların yüksek düzeyde gerçekleştiğini belirttikleri değerler ise \% 72.3 oranıyla "Dayanışma içinde olma", \% 71.6 oranıyla "Saygı duyma" ve \% 70.8 oranıyla da "Sorumluluk sahibi olma" biçimindedir.

Tablo 4. Katılanların “Genel Hareket Bilgi ve Becerileri” öğrenme alanına ilişkin kazanımların gerçekleşme düzeyine yönelik görüşleri

\begin{tabular}{lrrrrrr}
\hline $\begin{array}{l}\text { Genel Hareket Bilgi ve Becerileri Öğrenme Alanı Ka- } \\
\text { zanımları (N= 1118) }\end{array}$ & \multicolumn{2}{c}{ Evet } & \multicolumn{2}{c}{ Kısmen } & \multicolumn{2}{c}{ Hayır } \\
\cline { 2 - 7 } & $\mathrm{f}$ & $\%$ & $\mathrm{f}$ & $\%$ & $\mathrm{f}$ & $\%$ \\
\hline $\begin{array}{l}\text { Genel ısınma ve soğuma hareketlerini alışkanlık hâ- } \\
\text { line getirme }\end{array}$ & 569 & 50.9 & 129 & 11.5 & 420 & 37.6 \\
$\begin{array}{l}\text { Beden eğitimi dersi fiziksel etkinlikler yoluyla koor- } \\
\text { dinasyonunu geliştirme }\end{array}$ & 561 & 50.2 & 179 & 16.0 & 378 & 33.8
\end{tabular}




\begin{tabular}{lrrrrrr}
\hline Genel Hareket Bilgi ve Becerileri Öğrenme Alanı Ka- & \multicolumn{2}{c}{ Evet } & \multicolumn{2}{c}{ Kısmen } & \multicolumn{2}{c}{ Hayır } \\
\cline { 2 - 6 } zanımları (N= 1118) & $f$ & $\%$ & $f$ & $\%$ & $f$ & $\%$ \\
\hline $\begin{array}{l}\text { Oyun ve drama yoluyla kendini ifade etme yetenek- } \\
\text { lerini geliştirme }\end{array}$ & 452 & 40.4 & 222 & 19.9 & 444 & 39.7 \\
Oyun yoluyla stratejiler geliştirme becerisi kazanma & 523 & 46.8 & 184 & 16.5 & 411 & 36.8 \\
\hline
\end{tabular}

Tablo 4 incelendiğinde; beden eğitimi öğretim programında genel hareket bilgi ve beceriler öğrenme alanına yönelik belirlenen kazanımların gerçekleşme düzeyine yönelik en yüksek \% 50.9 oranıyla "Genel ısınma ve soğuma hareketlerini alışkanlık hâline getirme", gerçekleşme düzeyinin en düşük olduğu kazanım ise \% 39.7 oranıyla "Oyun ve drama yoluyla kendini ifade etme yeteneği geliştirme" olduğu gözlenmiştir.

\section{Tablo 5. Katılanların “Özel Hareket Bilgi ve Becerileri” alt öğrenme alanına ilişkin kazanımların gerçekleşme düzeyine ilişkin görüşleri}

\begin{tabular}{|c|c|c|c|c|c|c|}
\hline \multirow{2}{*}{$\begin{array}{l}\text { Özel Hareket Bilgi ve Becerileri Alt Öğrenme Alanı Kazanım- } \\
\text { ları ( } N=1118)\end{array}$} & \multicolumn{2}{|c|}{ Evet } & \multicolumn{2}{|c|}{ Kısmen } & \multicolumn{2}{|c|}{ Hayır } \\
\hline & $f$ & $\%$ & $f$ & $\%$ & f & $\%$ \\
\hline $\begin{array}{l}\text { Her hangi bir spor dalına özgü ısınma hareketlerini alışkanlık } \\
\text { hâline getirme }\end{array}$ & 516 & 56.3 & 168 & 14.9 & 434 & 28.8 \\
\hline Her hangi bir spor dalına özgü kuralları uygulayabilme & 596 & 53.3 & 160 & 14.3 & 362 & 32.4 \\
\hline Her hangi bir spor dalına özgü hareket becerilerini geliştirme & 599 & 53.6 & 169 & 15.1 & 350 & 31.3 \\
\hline $\begin{array}{l}\text { Her hangi bir spor dalına özgü kompleks hareket becerilerini } \\
\text { geliştirme }\end{array}$ & 530 & 47.4 & 211 & 18.9 & 377 & 33.7 \\
\hline $\begin{array}{l}\text { Her hangi bir spor dalına özgü savunma ve hücum becerileri- } \\
\text { ni, değişen durumlara göre uygulayabilme }\end{array}$ & 540 & 48.3 & 195 & 17.4 & 383 & 34.3 \\
\hline $\begin{array}{l}\text { Her hangi bir spor dalına özgü etkinliklerde kendisi ve çevresi } \\
\text { ile ilgili güvenlik ilkelerini uygulayabilme }\end{array}$ & 536 & 47.9 & 209 & 18.7 & 373 & 33.4 \\
\hline $\begin{array}{l}\text { Her hangi bir spor etkinliğinde kontrollü davranış ve adil } \\
\text { oyun ilkeleri sergileyebilme }\end{array}$ & 610 & 54.6 & 184 & 16.5 & 324 & 29.0 \\
\hline $\begin{array}{l}\text { Her hangi bir spor etkinliğinde bireysel farklılıkları olan arka- } \\
\text { daşları ile olumlu etkileşim içerisine girebilme }\end{array}$ & 680 & 60.8 & 168 & 15.0 & 270 & 24.2 \\
\hline $\begin{array}{l}\text { Her hangi bir spor etkinliğinde karşılaştğı problemler için } \\
\text { önlemler alabilme }\end{array}$ & 594 & 53.1 & 184 & 16.5 & 340 & 30.4 \\
\hline $\begin{array}{l}\text { Her hangi bir spor dalına özgü müzikler, danslar ve gelenek- } \\
\text { sel oyunlar ile ilgili etkinliklere katılarak evrensel kültür de- } \\
\text { ğerlerini tanıma }\end{array}$ & 494 & 44.2 & 199 & 17.8 & 425 & 38.0 \\
\hline $\begin{array}{l}\text { Her hangi bir spor etkinliğine katllarak rekabet ve işbirliğine } \\
\text { uygun tutum ve davranışlar sergileyebilme }\end{array}$ & 615 & 55.0 & 169 & 15.1 & 334 & 29.9 \\
\hline $\begin{array}{l}\text { Her hangi bir spor etkinliğine kattlarak güven duygusunu ge- } \\
\text { liştirme }\end{array}$ & 628 & 56.2 & 150 & 13.4 & 340 & 30.4 \\
\hline $\begin{array}{l}\text { Her hangi bir spor etkinliğinde araçları amacına uygun ve } \\
\text { doğru kullanabilme }\end{array}$ & 690 & 61.7 & 152 & 13.6 & 276 & 24.7 \\
\hline
\end{tabular}

Tablo 5'de; özel hareket bilgi ve becerileri alt öğrenme alanına yönelik kazanımların gerçekleşme düzeylerine ilişkin katılanların görüşleri yer almaktadır. Sonuçlar incelendiğinde; en yüksek \% 61.7 oranıyla "Her hangi bir spor etkinliğinde araçları amacına uygun ve doğru kullanabilme", \% 60.8 oranıyla "Her hangi bir spor etkinliğinde bireysel farklılıkları olan arkadaşları ile olumlu etkileşim içerisine girebilme" ve \%56.3 oranıyla da "Her hangi bir spor dalına özgü ısınma hareketlerini alışkanlık hâline getirme" kazanımlarının gerçekleştiği ifade edilirken, katılanların en düşük oranda gerçekleștiğini ifade ettikleri kazanımlar ise; \% 38 oranıyla "Her hangi bir spor dalına özgü müzikler, danslar ve geleneksel oyunlar ile ilgili etkinliklere katlarak evrensel kültür değerlerini tanıma", \% 34.3 oranıyla "Her hangi bir spor dalına özgü savunma ve hücum becerilerini, değişen durumlara göre uygulayabilme" ve \% 33.7 oranılla da "Her hangi bir spor dalına özgü kompleks hareket becerilerini geliştirme" olarak ifade edilmiştir. 
Tablo 6. Katılanların "Kişisel Gelişim ve Sağlıklı Yaşam" alt öğrenme alanına ilişkin kazanımların gerçekleşme düzeyine ilişkin görüşleri

\begin{tabular}{|c|c|c|c|c|c|c|}
\hline \multirow{2}{*}{$\begin{array}{l}\text { Kişisel Gelişim ve Sağlıklı Yaşam Alt Öğrenme Alanı Ka- } \\
\text { zanımları ( } N=1118)\end{array}$} & \multicolumn{2}{|c|}{ Evet } & \multicolumn{2}{|c|}{ Kısmen } & \multicolumn{2}{|c|}{ Hayır } \\
\hline & $f$ & $\%$ & $f$ & $\%$ & $f$ & $\%$ \\
\hline $\begin{array}{l}\text { Kendisine uygun olan serbest zaman etkinliklerine de- } \\
\text { ğer vererek katılma }\end{array}$ & 627 & 56.1 & 179 & 16.0 & 312 & 27.9 \\
\hline $\begin{array}{l}\text { Sağlıklı yaşam için çevredeki kişileri düzenli fiziksel et- } \\
\text { kinlik yapmaya teşvik etme }\end{array}$ & 564 & 50.4 & 164 & 14.7 & 390 & 34.9 \\
\hline $\begin{array}{l}\text { Fiziksel uygunluğu geliştirmek için, çevredeki kişileri } \\
\text { düzenli olarak fiziksel etkinlik yapmaya özendirme }\end{array}$ & 487 & 43.6 & 197 & 17.6 & 434 & 38.8 \\
\hline Sağlıklı beslenmeyi yaşam biçimi hâline getirme & 445 & 39.8 & 205 & 18.3 & 468 & 41.9 \\
\hline $\begin{array}{l}\text { Fiziksel gelişimi hakkında bilgi almak için periyodik test- } \\
\text { lere katılma }\end{array}$ & 387 & 34.6 & 201 & 18.0 & 530 & 47.4 \\
\hline $\begin{array}{l}\text { Kişisel bakım ve temizliğini yapmayı alışkanlık hâline } \\
\text { getirme }\end{array}$ & 611 & 54.7 & 174 & 15.6 & 333 & 29.8 \\
\hline Kendine uygun fiziksel etkinlik hedefleri belirleme & 570 & 51.0 & 181 & 16.2 & 367 & 32.8 \\
\hline $\begin{array}{l}\text { Sportif etkinliklerde kullanacağı ürünleri seçerken bi- } \\
\text { linçli hareket etme }\end{array}$ & 583 & 52.1 & 168 & 15.0 & 367 & 32.8 \\
\hline
\end{tabular}

Tablo 6'da kişisel gelişim ve sağlıklı yaşam alt öğrenme alanı kazanımlarından "Kendisine uygun olan serbest zaman etkinliklerine değer vererek katılma" \% 56.1, "Kişisel bakım ve temizliğini yapmayı alıșkanlık hâline getirme" \% 54.7 ve "Sportif etkinliklerde kullanacă̆ı ürünleri seçerken bilinçli hareket etme" kazanımları \% 52.1 ile en yüksek oranla gerçekleştirildiği; "Fiziksel gelişimi hakkında bilgi almak için periyodik testlere katılma" \% 47.4, "Sağlıklı beslenmeyi yaşam biçimi hâline getirme" \% 41.9 ve "Fiziksel uygunluğu geliştirmek için, çevredeki kişileri düzenli olarak fiziksel etkinlik yapmaya özendirme" \% 38.8 oranıyla da bu kazanımların gerçekleşmediği belirtilmiştir.

Tablo 7. Katılanların “Spor Bilinci ve Organizasyonları” alt öğrenme alanına ilişkin kazanımların gerçekleşme düzeyine yönelik görüşleri

\begin{tabular}{|c|c|c|c|c|c|c|}
\hline \multirow{2}{*}{$\begin{array}{l}\text { Spor Bilinci ve Organizasyonları Alt Öğrenme Alanı Ka- } \\
\text { zanımları }(\mathrm{N}=1118)\end{array}$} & \multicolumn{2}{|c|}{ Evet } & \multicolumn{2}{|c|}{ Kısmen } & \multicolumn{2}{|c|}{ Hayır } \\
\hline & $f$ & $\%$ & $f$ & $\%$ & $f$ & $\%$ \\
\hline “Olimpizm felsefesini” kavrama & 386 & 34.5 & 213 & 19.1 & 519 & 46.4 \\
\hline $\begin{array}{l}\text { Spor organizasyonlarının gerçekleştirilmesinde etkin } \\
\text { görev alma }\end{array}$ & 486 & 43.5 & 159 & 14.2 & 473 & 42.3 \\
\hline $\begin{array}{l}\text { Spor organizasyonlarına katılarak bağlı olduğu grubu/ } \\
\text { takımı en iyi şekilde temsil etme }\end{array}$ & 528 & 47.2 & 171 & 15.3 & 419 & 37.5 \\
\hline Güncel spor olaylarını değerlendirebilme & 528 & 47.2 & 148 & 13.2 & 442 & 39.5 \\
\hline $\begin{array}{l}\text { Spor organizasyonları ve olimpiyat oyunlarının toplum- } \\
\text { lar arası etkileşimdeki rolünü değerlendirebilme }\end{array}$ & 501 & 44.8 & 173 & 15.5 & 444 & 39.7 \\
\hline $\begin{array}{l}\text { Ülkemizdeki ve dünyadaki spor politikalarını değerlen- } \\
\text { direbilme }\end{array}$ & 478 & 42.8 & 180 & 16.1 & 460 & 41.1 \\
\hline
\end{tabular}

Tablo 7'de; öğretim programının spor bilinci ve organizasyonları alt öğrenme alanında katılanların \% 46.4'ü “Olimpizm felsefesini kavrama", \% 42.3'ü "Spor organizasyonlarının gerçekleştirilmesinde etkin görev alma" ve \% 41.1'i de “Ülkemizdeki ve dünyadaki spor politikalarını değerlendirebilme" kazanımlarının en düşük düzeyde gerçekleştiğini belirtmişlerdir. 
Tablo 8. Beden eğitimi derslerinin daha verimli ve etkili yürütülmesi için katılanların alt temalara yönelik önerileri

\begin{tabular}{|c|c|c|}
\hline Öneriler & $f$ & $\%$ \\
\hline \multicolumn{3}{|l|}{ Fiziki Olanaklara Yönelik Öneriler } \\
\hline Her okulda spor salonu bulunmalı & 35 & 8.3 \\
\hline Araç-gereç ve malzeme yeterli olmalı & 24 & 5.7 \\
\hline Her okulda giyinme dolabı ve duş olmalı & 7 & 1.7 \\
\hline \multicolumn{3}{|l|}{ Eğitim-Öğretim Sürecine Yönelik Öneriler } \\
\hline Ders uygulamalı olmalı, "ver topu oynasın" biçiminde işlenmemeli & 55 & 13.1 \\
\hline Ders ilgi görmeli, önem verilmeli, verimli olmalı & 43 & 10.2 \\
\hline İçerik zenginleştirilmeli, çeşitlendirilmeli, farklı spor dalları öğretilmeli & 31 & 7.4 \\
\hline İlgi alanları dikkate alınarak kişiye özgü uygulamalar yapılmalı & 21 & 5.0 \\
\hline Ders saatinde başka ders işlenmemeli, programa uygun işlenmeli & 11 & 2.6 \\
\hline Temelden çocuklar spor eğitimine alıştrrılmalı & 8 & 1.9 \\
\hline Ders konusu öğrencinin ilgi ve isteğine göre belirlenmeli & 7 & 1.7 \\
\hline Derslerde sporcu geçmişi olanlardan destek alınmalı & 6 & 1.4 \\
\hline Derste öğrenilenler yaşam biçimi haline dönüştürülmeli & 5 & 1.2 \\
\hline $\begin{array}{l}\text { Diğer (ısınma ve soğuma hareketleri branşa özgü yapılmalı, not verilmemeli, eşofman } \\
\text { giyilmeli, kız-erkek ayrılmalı) }\end{array}$ & 12 & 2.9 \\
\hline \multicolumn{3}{|l|}{ Öğretmenlere Yönelik Öneriler } \\
\hline Öğretmenler bilinçli ve sorumluluk sahibi olmalı & 21 & 5.0 \\
\hline Öğretmenler öğrencilerin isteklerine önem verilmeli & 15 & 3.6 \\
\hline Öğretmeler agresif ve sinirli değil güler yüzlü olmalı & 9 & 2.1 \\
\hline Öğretmenler öğrencinin sağlık ve diğer sorunlarına duyarlı olmalı & 7 & 1.7 \\
\hline Öğretmenlerin fiziki görünümleri fit olmalı & 4 & 0.9 \\
\hline \multicolumn{3}{|l|}{ Ders Dışı Spor Faaliyetlerine Yönelik Öneriler } \\
\hline Spor organizasyonları çoğaltılmalı & 11 & 2.6 \\
\hline Spor dallarına katılım teşvik edilmeli & 8 & 1.9 \\
\hline Geleceğe dönük alt yapı kazandırılmalı & 6 & 1.4 \\
\hline Yetenekli öğrenciler ayrıca yetiştirilmeli & 5 & 1.2 \\
\hline Okul takımdaki öğrencilere ayrıcalık tanınmamalı & 5 & 1.2 \\
\hline \multicolumn{3}{|l|}{ Karar Vericilere Yönelik Öneriler } \\
\hline Her okulda en az bir beden eğitimi öğretmeni olmalı, ders boş geçmemeli & 35 & 8.3 \\
\hline Ders saatleri artırılmalı & 16 & 3.8 \\
\hline Lise düzeyinde derse önem verilmeli & 7 & 1.7 \\
\hline Ailelere bu ders benimsetilmeli & 6 & 1.4 \\
\hline Toplam & 420 & 100.0 \\
\hline
\end{tabular}

Not: Birden fazla madde işaretlenmiştir.

Tablo 8'de beden eğitimi derslerinin daha verimli ve etkili işlenmesi için mezunların önerilerine yer verilmiştir. Katılanlar okulların fiziki olanaklarına yönelik spor salonu, araç-gereç ve malzeme eksikliğinin giderilmesini; eğitim-öğretim sürecine yönelik "ver topu oynasın" biçiminde değil, derse önem verilerek zenginleştirilmiş bir içerikle işlenmesini önermektedirler. Beden eğitimi öğretmenlerine yönelik ise; öğretmenlerin bilinçli ve sorumluluk sahibi olmalarını, öğrencilerin ilgi ve isteklerine değer vermelerini, ders dışı spor faaliyetlerine yönelik spor organizasyonlarının çoğaltılmasını ve spor dallarına katılımın teşvik edilmesini önermektedirler. Karar vericilere yönelik de derslerin boş geçmemesini, beden eğitimi öğretmen eksikliğinin giderilmesini ve ders saatlerinin artırılmasını yoğunlukla önermektedirler.

\section{Tartışma}

Lise mezunlarının 2009-2017 yıllarında uygulanan ortaöğretim beden eğitimi dersi öğretim programının kazanımlarının gerçekleşme düzeyine ilişkin görüşlerini ve beden eğitimi dersinin daha etkili ve verimli işlenmesine yönelik önerilerini belirlemek amacıyla yapılan bu araştırmada mezunlar; öğretim programının "temel becerilere" ilişkin kazanımların gerçekleşme düzeyine ait görüşleri incelendiğinde; hiçbir kazanımın yüksek oranla gerçekleştiğine yönelik görüş belirtilmemiştir. En yüksek \% 59.9 oranıyla gerçekleştiği belirtilen kazanım “iletişim kurma” becerisindedir. Bloom (1976-2012), okulda tam öğrenmenin gerçekleşebilmesi için, öğrenme oranının yüzde 75-85 düzeyinde gerçekleşmesi gerektiğini öngörmektedir (s. 308). Bloom'un belirlediği ölçüt dikkate alındığında; beden eğitimi öğretim programı te- 
mel beceriler alanındaki kazanımların gerçekleşmesi beklenen düzeyin altında kaldığı anlaşılmaktadır. Bununla birlikte yapılan analizler sonucunda "değerlere" ilişkin kazanımların gerçekleşme düzeyinin temel becerilere oranla daha yüksek oranda olduğu görülmektedir (Tablo 3). Değerler alanında en düşük düzeyde gerçekleştiği ifade edilen kazanımlar "Vatanseverlik", "Estetik anlayış" ve "Centilmence davranma" olduğu gözlenmektedir. Bu bulgulardan hareketle; gerek temel beceriler ve gerekse değerlere ilişkin kazanımların gerçekleştirilmesinde sadece beden eğitimi öğretim programı değil diğer öğretim programlarının da (Fen Bilgisi, Türkçe, Matematik vb.) hedefleri arasında olduğundan, beden eğitimi dersi marifetiyle bu kazanımların gerçekleşmesini beklemek programa ve uygulayıcılarına haksızlık olacağı düşüncesiyle bu makalede tartışmayı derinleştirme ihtiyacı duyulmamış, tartş̧ma doğrudan beden eğitimi ve sporla ilintili kazanımlara odaklanılmıştr.

Beden eğitimi öğretim programında Genel Hareket Bilgi ve Beceriler Öğrenme Alanına yönelik dört kazanım bulunmakta ve araştırma sonuçlarına göre; genel hareket bilgi ve becerileri öğrenme alanında belirlenen kazanımların gerçekleşme oranı, Bloom'un tam öğrenme standartlarının altında kaldığı görülmektedir. En yüksek oranla (\% 50.9) “Genel ısınma ve soğuma hareketlerini alışkanlık hâline getirme" kazanımının gerçekleştiği anlaşımaktadır (Tablo 4). Fiziksel aktiviteye başlamadan önce bedenin fizyolojik, anatomik ve psikolojik olarak harekete hazır hale gelmesinde, hareketin bitiminde de kasların gevşetilerek normale dönmesinde ısınma ve soğuma hareketleri önem taşımaktadır (Bompa ve Haff, 2015, s.81, 133; Arslan, Gökhan ve Aysan, 2011). Bu gerekçeyle bu kazanım öğretim programına alınmış, ısınma ve soğuma hareketleri her beden eğitimi dersinde mutlaka uygulanması gereken bir kural konumundadır. Buna rağmen katılımcıların yeterli düzeyde böyle bir alışkanlık kazanmadıklarını belirtmiş olmaları, beden eğitimi derslerinde uygulayıcıların ders başında ve sonunda bu koşulu yerine getirmede ilgisiz kaldıklarını veya eğlenceli hale getirmediklerini düşündürmektedir. Amatör sporcularda ısınma alışkanlığı ve bilgi düzeylerine yönelik yapılan çalışmada; atletlerin sadece \% 47.8'i ısınma hareketlerini, \% 17.3'ü de dinlenme hareketlerini yapttkları bulunmuştur (Arslan, Gökhan ve Aysan, 2011). Amatör spor kulüplerinde oynayanların büyük çoğunluğu lise öğrencisi veya mezun olmuş kişiler olarak düşünüldüğünde, okulda kazandırılmayan veya kazandırılamayan bu alışkanlığın, bireylerin sosyal ve mesleki (kariyer) yaşamına da aktarılamadığının bir kanıtı olarak görülebilir.

Diğer yandan, genel hareket bilgi ve beceriler öğrenme alanı kazanımlarından "Oyun ve drama yoluyla kendini ifade etme yeteneği geliştirme" kazanımının katlımcıların \% 40.4'ü en düşük oranla gerçekleşmediğini ifade etmişlerdir. Oyun, beden eğitimi derslerinde çocukların en fazla severek katıldıkları etkinlikler arasındadır. Çünkü oyun insan doğasının bir özelliğidir (Huizinga, 1955-1995, s. 16). Oyun çocuğun sosyal, bilişsel ve motor gelişimine etkisinden dolayı beden eğitimi öğretim programlarında yer almakta (Graham, Holt \& Parker, 2001, s. 636) ve oyun yoluyla öğretim; öğrenme ve öğretme sürecinde de etkili öğretim tekniklerinden birisidir (Arnold, 1995, s. 125; Pehlivan, 2005; Topbaş, 2013). Diğer yandan, aynı kazanımda ifade edilen "drama" ise çocuğun yaratıcılığını geliştirmede, problem çözme becerisinde ve kendini ifade etmede önemli bir araçtır (McCaslin, 2016). Beden eğitimi derslerinde oyun ve dramanın etkili olabilmesi; bu etkinliğin kurgulanması, planlanması, organizasyonu ve drama esnasında güvenli bir ortamın (psikolojik ve fiziksel) oluşturulması, oyun ve dramanın sonlandırılarak sınıf ortamında değerlendirilmesi süreçlerine bağlıdır (Gönen ve Uyar Dalkılıç, 1998). Diğer yandan oyun ve drama, beden eğitimi ve spor öğretmeni yetiştiren öğretim programlarında da ders olarak yer almaktadır. Buna rağmen, bu kazanımın çok düşük düzeyde gerçekleştirilmiş olmasının nedeni; öğretmen yetiştiren kurumlarda drama ve oyun konusunda yeterli ve donanımlı öğretim elemanlarının bulunmamasından dolayı; eksik bilgi ve beceriyle mezun olan öğretmen adayları, bulundukları okul ve sınıflarında bu kazanıma yönelik etkinlik planlama ve yürütmede öz-yeterlik eksikliğinden kaynaklandığı ileri sürülebilir.

Öğretim programında özel hareket bilgi ve becerileri alt öğrenme alanına yönelik olarak 13 kazanım bulunmaktadır. Bu kazanımların gerçekleşme düzeylerine ilişkin katılanların görüşleri incelendiğinde (Tablo 5), bütün kazanımların yine Bloom'un belirlediği ölçütün altında kaldığı gözlenmektedir. En yüksek oranda gerçekleştiğine yönelik görüş belirtilen kazanım \% 61.7 oranıyla "Her hangi bir spor etkinliğinde araçları amacına uygun ve doğru kullanabilme" olduğu görülmektedir. Bu kazanımın diğer kazanımlara oranla daha yüksek oranda gerçekleşmesinin nedeni öğretmenlerin "voleybol topuna ayakla vurulmaz!" uyarılarının ders ortamında sıklıkla yapılmış olması ve bu davranışı gösterenlerin de cezalandırılı̆̆ından (Pehlivan, 2012) kaynaklandığı söylenebilir. Ancak öğretim programında böyle bir kazanımın varlığı ve bir eğitim hedefi haline getirilmiş olması program açısından gereksiz olduğu ileri sürülebilir. Çünkü eğitimde farklı ders materyallerinin farklı biçimde ve farklı etkinliklerde kullanılması yatıcılı̆ı geliştirmesi bakımından istenilen bir durumdur (Davison, 1989). Ders materyallerinin farklı amaçları gerçekleştirmede kullanmak yaratıcılığı geliştirmenin yollarından birisi olarak da görülmektedir (Montessori, 1975). Bu nedenle, öğretim programında sınıf yönetimi kapsa$\mathrm{m}$ içerisinde gerçekleştirilebilecek nitelikte olan bir kazanımın programa alınması, "öğretmen konuşurken dinlenmesi gerekir!" gibi bir kazanımı programa almakla eşdeğer olarak görmek gerekir ki bazı kazanımlar programa alınmadan örtük olarak da kazandırılabilmelidir. 
Yine, özel hareket bilgi ve becerileri alt öğrenme alanında en düşük düzeyde gerçekleştiği ifade edilen kazanım ise \% 38 oranıyla "Her hangi bir spor dalına özgü müzikler, danslar ve geleneksel oyunlar ile ilgili etkinliklere katılarak evrensel kültür değerlerini tanıma" olduğu anlaşımaktadır. Bu kazanımın düşük düzeyde gerçekleşmesinin nedeni; müzik, dans ve geleneksel oyunlara yönelik beden eğitimi dersi kapsamında bu tür etkinliklere fazla yer verilmediği, beden eğitimi ve spor öğretmenlerinin müzik ve dans konusunda yeterli donanıma sahip olmadıklarından kaynaklandığı söylenebilir. Bununla birlikte, bu tür kazanımların gerçekleşmesi çocuğun ders dışı etkinliklere katımasını gerektirmektedir. Ancak okullarımızda ders dışı etkinliklere katılımda öğrenci sayısının sınırlı tutulması bunu engellemektedir. Özel hareket bilgi ve becerileri alt öğrenme alanında bulunan "Her hangi bir spor dalına özgü savunma ve hücum becerilerini, değişen durumlara göre uygulayabilme" (\%34.3) ve "Her hangi bir spor dalına özgü kompleks hareket becerilerini geliştirme" (\%33.7) gibi kazanımların da yine düşük düzeyde gerçekleştiğine yönelik bulgular elde edilmiştir. Bu iki kazanım incelendiğinde; seçili bir spor dalında lise mezunlarının yeterli düzeyde bilgi ve beceriye sahip olmadığı anlaşıımaktadır. Beden eğitimi ve spor derslerinde okul ve çevre olanaklarına bağlı olarak çeşitli spor becerileri kazandırılmak hedeflenmektedir. Seçili spor dallarının öğretimi teknik, taktik ve bilgi gerektiren bir içerikle aşamalı olarak işlenmesi gerekir. Spor dallarına yönelik özel bilgi ve becerilerin kazandırılamamış olması; derslerde öğretmenlerin planlı bir ders uygulamadıkları "ver topu oynasın!" anlayışııın sonucuna bağlanabilir. Yapılan bu araştırmada mezunların beden eğitimi derslerine öğretmenlerin ilgi göstermesi, derse önem verilmesi ve her dersin planlı biçimde işlenmesi, aynı etkinliklerin sürekli tekrar edilmemesi gibi araştırmaya katılanların önerilerde bulunmuş olması da (Tablo 8) bu iki kazanıma yönelik sonuçları destekler niteliktedir. Bununla birlikte, çocukların beden eğitimi derslerinde aynı etkinlikleri tekrar etmeme, farklı spor dallarını öğrenme ve kendilerini bu yönde geliştirme gibi ilgi ve beklentilerinin yüksek olduğu da yapılan çalışmalarda bulmuştur (Pehlivan, 2013; Özcan ve Mirzeoğlu, 2014).

Beden eğitimi öğretim programının kişisel gelişim ve sağlıklı yaşam alt öğrenme alanında sekiz kazanım bulunmaktadır. Belirlenen kazanımlardan hiç birisinin \% 75-85 düzeyinde gerçekleşmediği anlaşımaktadır (Tablo 6). Bu kazanımlardan gerçekleşme düzeyi en düşük olduğu belirtilen kazanımlardan birisi \% 47.4 oranıyla "Fiziksel gelişimi hakkında bilgi almak için periyodik testlere katılma" ve bir diğeri de \% 41.9 oranıyla "Sağlıklı beslenmeyi yaşam biçimi hâline getirme"dir. Son yıllarda fiziksel aktiviteye katılım ile sağlık kavramları ilişkilendirilmektedir. Sağlığın geliştirilmesinde ve korunmasında fiziksel aktivitenin önemi yapılan çalışmalarla da vurgulanmaktadır (Miller, Balady \& Fletcher, 1997; Kokkinos \& Fernhall, 1999; Robbins ve diğerleri, 2006; Sallis ve diğerleri, 2000). Bununla birlikte, Dünya Sağlık Örgütü (WHO, 2013, s.41) ve ulusal kurumlar da bu yönde raporlar hazırlamakta (Sağlık Bakanlığı, 2018) ve sağlık-spor ilişkisinin önemine vurgu yapmaktadırlar. Ancak öğretim programında belirtilen sağlıkla ilgili periyodik testlere katılma kazanımının gerçekleşebilmesi için periyodik ölçümlerin neler olduğu ve bu ölçümlerin nerede ve nasıl yapılacağına yönelik bir sistemin kurulmasına ve bu merkezlerin bulunmasına bağlıdır. Fiziksel gelişime yönelik ölçümler Sağlık ve Milli Eğitim Bakanlığının (2017, http://okulsagligi.meb.gov.tr/meb) her öğrenci için Sağlıkla İlgili Fiziksel Uygunluk Karnelerinin (FUK) hazırlanmasına yönelik uygulamanın 2016-2017 yılından itibaren başlatılmış olması bu ve benzer kazanımların gerçekleşmesinde işlevsel olabilir, ancak mezun olanların bu ölçümlerin periyodik olarak yapılmasına yönelik merkezlerin yok denecek kadar az olması, var olan bu merkezlerin de sadece profesyonellere hizmet ediyor olması bu kazanımın gerçekleşmesini engellediği söylenebilir. Diğer yandan sağlıkı beslenme alışkanlığı kazandırma da yine beden eğitimi öğretim programının kapsamı içerisine alınmış olması sağlık-spor ve beslenme ile ilişkilendirilmektedir. Elbette sağlıklı beslenme kaliteli bir yaşam için önemli bir unsurdur. Bu da beslenme bilgisi ve çevresel koşullarla ilişkilidir ve sadece beden eğitimi öğretim programının konusu değildir, sağıık ve biyoloji gibi diğer öğretim programlarının kapsamı içerisinde disiplinler arası yaklaşımla ele alınması gereken bir durumdur.

Beden eğitimi ve spor öğretim programının spor bilinci ve organizasyonları alt öğrenme alanına ilişkin altı kazanım yer almakla birlikte en düşük düzeyde gerçekleştiği ifade edilen öğrenme alanı olduğu görülmektedir (Tablo 7). Gerçekleşme oranı \% 34.5 ile \% 47.2 arasında değişmektedir. Katılanların en düşük düzeyde gerçekleştiği ifade edilen kazanım \% 46.4 oranıyla "Olimpizm felsefesini kavrama" olduğu görülmektedir. Olimpizm felsefesi, spor kültürü oluşturmada etkili ve evrensel bir değer olması nedeniyle, öğretim programlarında yer almaktadır. Ayrıca, dünyada en büyük organizasyon olan olimpiyat oyunları düzenlemede de bu kültürün oluşması ve yerleşmesi etkili olabilmektedir (Hürriyet Gazetesi, 2012). Öğretim programları aracılığıyla olimpizm kültürünün oluşturulmasının hedeflenmesine rağmen, bu kazanımın çok düşük düzeyde gerçekleştiğinin ifade edilmesi; öğretmenlerin bu konudaki inanç eksikliğinden, bilgisizliğinden ve derslerinde yeteri kadar yer vermediklerinden kaynaklandığı ileri sürülebilir. Şöyle ki; Gümüş ve arkadaşlarının (2016) ortaöğretim öğrencilerinin fair-play davranışlarına yönelik eğilimleri üzerine yaptıkları çalışmada, özellikle erkek öğrencilerin yüksek düzeyde fair-play anlayışından uzak bir oyunu tercih ettiklerini, Kayışoğlu ve arkadaşlarının (2015) ortaokul öğrencilerinin sportmenlik davranışlarına ilişkin çalışmasında ise cinsiyete göre farklılaşmadığı, ancak spor salonuna sahip olma durumuna göre anlamlı biçimde farklılaştğı bulunmuştur. Diğer yandan olimpizm felsefesi 
dürüst oyun, centilmenlik, adil oyun, dayanışma, işbirliği ve rakibe saygı gibi kavramları içinde barındırmaktadır (Yıldıran, 2011; Erdemli, 2008, s.414). Bu kavramların okulda kazandırılarak toplumsal olarak spor kültürü oluşturulması hedeflenmektedir. Bu hedefe ulaşmada eğitim ve öğretim süreci içerisinde çok sayıda spor organizasyonları öğrenciler tarafindan yapılarak, çocuğun bu kavramlarla etkileşim halinde olmasının etkili olabileceği düşünülmektedir. Ancak gerek okul içi ve gerekse okullar arası spor organizasyonları ve yarışmaları "kazanmayı!" odak haline getirmiş olması, "her ne pahasına olursa olsun mutlaka kazanmalıyız!" yaklaşımı da olimpizm felsefesi ve spor kültürünün oluşmasında engel oluşturduğu söylenebilir.

Araştırmanın bir diğer amacı da beden eğitimi ve spor derslerinin daha nitelikli yapılabilmesi için mezunların önerilerine ilişkindi. Açık uçlu soruya verilen yanıtların içerik analizinde katılanların; okulun fiziki olanaklarına yönelik spor salonu, araç, gereç ve malzeme sorununun giderilmesi konusunda yoğunluk yaşandığı anlaşılmaktadır. Geçmişe dönük yapılan araştırma sonuçları irdelendiğinde; beden eğitimi derslerinin en önemli sorununun spor tesisi ve araç-gereç eksikliği olduğu (Aydın, 2002; Baykoçak, 2002; Çılgın, 2003) ve günümüzde de tesis sorununun çözülmediği (Pehlivan, 2013; Özcan ve Mirzeoğlu, 2014; Demirhan ve ark., 2014) önemli ve düşündürücü bir bulgudur. Program hedeflerinin gerçekleştirilmesinde ve etkili bir beden eğitimi dersi için spor tesisinin ve ders materyallerinin önemli olduğu vurgulanmaktadır (Ballinger, 1993). Bu sorunun ortaya çıkmasında, okulların spora ilişkin altyapılarının eksik yapılmış olmasının etkisi bulunmaktadır. Okullar planlanırken spor, sanat, kültür, laboratuvar, atölye vb. alt yapısıyla bir bütün olarak birlikte planlanması arzulanan bir durumdur. Diğer yandan, eğitim-öğretim sürecine yönelik önerilerin başında derslerin "ver topu oynasın!" biçiminde değil planlı, programlı ve aşamalı biçimde işlenmesini, derse ilgi ve önem verilmesini, ders içeriğinin ve etkinliklerinin zenginleştirilmesi konusunda önerilerin yapılmış olması; beden eğitimi ve spor dersinin diğer derslere oranla statüsünün düşük düzeyde kaldığı sonucunu doğurmaktadır. Beden eğitimi derslerinde her öğrenciye yüksek not verilmesi de dersin önemini düşürdüğü ve öğretimin objektif biçimde değerlendirilmediği ileri sürülmektedir (Özcan ve Mirzeoğlu, 2014; Demirhan ve ark., 2014). Bununla birlikte, beden eğitimi ve spor dersinin uygun biçimde işlenip işlenmediği etkili biçimde denetlenmemesi de yine dersin amaca uygun verimli biçimde yürütülmesini olumsuz etkilediği söylenebilir. Örneğin, beden eğitimi ve spor dersiyle ilgili üniversite sınavlarında soru sorulmaması öğrenci, öğretmen, aile ve okul yönetiminin dikkatini bu derse vermemelerine neden olabilir. Öğretmenlere yönelik önerilerin başında; öğretmenlerin bilinçli ve sorumluluk sahibi olmaları ve öğrencilerin isteklerini dikkate almaları gelmektedir. Öğretmenlik mesleğine yönelik yapılan araştırmalarda en iyi öğretmen özellikleri arasında alan bilgisine sahip, sorumluluk duygusu gelişmiş ve mesleğini önemseme gibi özellikler ilk sıralarda sayılmaktadır (Özkan ve Arslantaş, 2013; Demirhan, 2006, s. 30). Ayrıca, beden eğitimi öğretmenlerinin genel kültür, mesleki bilgi ve alan bilgisine de sahip olmaları gerekmektedir (Gordon, 1993). Bu ve benzer özelliklere sahip olmayan, bu özellikleri içselleştirememiş öğretmenlerin alanda görev yapıyor olmaları, beden eğitimi öğretmeni yetiştiren kurumların niteliğini tartışıır hale getirdiği ileri sürülebilir.

Araştırmaya katılanların beden eğitimi derslerinin daha nitelikli olabilmesi için ders dışı spor etkinliklerine yönelik yaptıkları önerilerin başında; spor organizasyonlarının çoğaltılarak, spor etkinliklerine katılımın teşvik edilmesi gelmektedir (Tablo 8). Ders dışı okul spor etkinliklerinin amacı çocukların bireysel yeteneklerini geliştirmektir. Sınıflar arası veya okullar arası spor yarışmaları beden eğitimi öğretim programının amaçlarını gerçekleştirmede de önemli bir değere sahiptir (Siedentop \& Tannehil, 2000, s. 308; Gallahu \& Donnelly, 2003, s. 355). Okullarda spor organizasyonlarının yeterli düzeyde yapılmadığı, derslerde kendini ifade etme firsat bulamayan ve yetenekli çocukların kendilerini geliştirmeden yoksun kalmaları bu önerilerin yapılmasına neden olmuş olabilir. Bir diğer öneri teması ise karar vericilere yöneliktir; karar vericilerin başında merkezi yönetim ve okul yöneticileri gelmektedir. Karar vericilere yönelik her okulda beden eğitimi öğretmeni bulundurmaları, ders dışı spor etkinliklerini desteklemeleri ve beden eğitimi ders saatlerinin artırılmasına yönelik öneriler önem göstermektedir. Okul yönetiminin beden eğitimi dersi ve ders dışı spor etkinliklerine yönelik ilgisizliği sporu bırakma nedenleri arasında bile sayılmaktadır (Pehlivan, 2013). Bu önerileri, Türkiye'de her okulda bir beden eğitimi öğretmeninin bulunmadığı gerçeğinin bir yansıması olarak görmek gerekir. Eğitim ve öğretimin temel ögelerinden olan öğretmenin okullarda eksik veya hiç olmaması öğretim programının yürütülmesini olumsuz etkilemesi kaçınılmazdır. Türkiye' de şu an için atama bekleyen öğretmen sayısı dikkate alındığında; beden eğitimi öğretmeni açığının karşılanmaması (http://www.egitimajansi.com); derslerin boş geçmesi nedeniyle öğretim programının başarısını düşürdüğü ileri sürülebilir. Derslerin boş geçmesinin bir diğer nedeni de beden eğitimi öğretmenlerinin derslerini inmal edip okullar arası spor etkinlikleriyle meşgul olması, il veya ilçe lig heyetlerinde görev almalarından kaynaklanıyor olabilir. Bir diğer önemli öneri ise ders saatlerinin artırılmasına yöneliktir. Yapılan başka çalışmalarda da ders saatlerinin yetersiz olması sorun olarak görülmüş ve artııılmasına yönelik öneriler yapılmıştır (Taşmektepligil, Yılmaz ve Kılcıgil, 2006; Demirhan ve ark., 2008; Demirhan ve ark., 2014). Katılanların ders saatlerinin artırılmasını istemeleri; çocukların derslerinde yeteri kadar oyuna doymadıkları ve kendilerini ifade etme olanağı bulamadıklarının yanı sıra metropollerde 
oturanların okul dışında intiyacı olan oyun oynama veya fiziksel aktivite yapma olanaklarının sınırlılığından kaynaklandığı söylenebilir.

Sonuç olarak, bir öğretim programının hedeflerinin yüzde yüzünün gerçekleşmesi ideal bir durumdur. Ancak bu gerçekleşme düzeyine genellikle ulaşılamaz. Bu nedenle programın sadece etkililiği değil sistemin bütün öğelerinin (amaçları, içerik, öğretim durumları ve ölçme değerlendirme) tek tek analiz edilerek değerlendirilmesi gerekir (Erden, 1993, s. 15). Okullarda kimlerin öğrenip kimlerin öğrenemeyeceğini büyük çapta okulların koşulları belirlemekte, başka bir anlatımla öğrencilere sunulan öğretim hizmetinin niteliği de etkili olmaktadır (Bloom, 1976-2012, s.139). Buradan hareketle, yapılan bu araştırmada öğretim programında belirlenen kazanımların gerçekleşme düzeylerinin beklentilerin altında kaldığı söylenebilir. Bu çalışmada elde edilen veriler, katılanların mezun olduktan sonra bir veya iki yıllık bir zamanın geçmiş olması da çalışmanın sınırlılı̆ı olarak kabul edilebilir.

Elde edilen bulgular ışığında şunlar önerilebilir;

- Temel beceriler ve değerlere ilişkin ayrı bir çalışmanın diğer öğretim programlarıyla karşılaştırmalı biçimde yapılması,

- Beden eğitimi derslerinin, kazanımlarına yönelik aşamalı ve farklı spor dallarının öğretimi biçimde yapılması, çeşitlendirilmesi,

- Beden eğitimi ve spor öğretmeni yetiştiren kurumlarda drama eğitimine önem verilmesi, bu dersin drama eğitimi almış kişiler tarafindan yürütülmesi,

- Spor araç-gereçlerinin amaca uygun kullanılması, ısınma ve soğuma becerileri kazandırma ve beslenme bilgisi gibi kazanımların örtük olarak kazandırıması,

- Okullarda müzik ve dans derslerini yürütebilecek nitelikte öğretmenlerin yetiştirilmesi,

- Sağlık Bakanlığı ile işbirliği halinde; okuldan mezun olduktan sonra bireylerin fiziksel gelişimlerine yönelik periyodik ölçümlerin yapılabileceği merkezlerin kurulması ve her bir birey için izleme kartlarının oluşturulması,

- Spor kültürü oluşturmada okul içive okul dışı spor organizasyonlarının sayısının artrılması ve bu organizasyonların planlanmasında ve yürütülmesinde öğrencilerin aktif görev alması,

- Okul inşaatlarının spor tesisleriyle birlikte planlanması,

- Gerek program ögelerinin ve gerekse öğretimin değerlendirilmesine yönelik ölçme ve değerlendirmenin objektif biçimde yapılması,

- Her okulda bir beden eğitimi öğretmeni olacak biçimde atamaların yapılması, önerilmektedir

\section{Kaynakça}

---- "33.000 Beden Eğitimi Öğretmeni Atama Bekliyor", http://www.egitimajansi.com/ sitesinden 26.02.2018 tarihinde ulaşılmıştr.

Arnold, A. (1995). Çocuğunuz ve Oyun. (Çev. Ahmet Gümüş), İstanbul: Denge Yayınları.

Arslan, C., Gökhan, i. ve Aysan, H. A. (2011). Amatör sporcularda ısınma alışkanlığı ve bilgi düzeylerinin değerlendirilmesi. Klinik ve Deneysel Araşttrmalar Dergisi, 2 (2): 181-186.

Aydın, N. A. (2002). Ankara'daki özel ve resmi ortaöğretim kurumlarında görev yapan beden eğitimi öğretmenlerinin bazı mesleki niteliklerinin ve ders dışı çalışmalara katılmalarının karşılaştıııması. Yayımlanmamış yükseklisans tezi, Ankara: Gazi Üniversitesi.

Ballinger, D. A. (1993). Becoming an effective physical educator. Physical Educator, 50(1), 13-19.

Baykoçak, C. (2002). Beden eğitimi öğretmenlerinin mesleki sorunları ve tükenmişlik düzeyleri Bursa ili uygulaması. Yayımlanmamış yükseklisans tezi, Sakarya: Sakarya Üniversitesi.

Bloom, B. S. (1976-2012). İnsan Nitelikleri ve Okulda Öğrenme. (Çev. Durmuş Ali Özçelik), 2. Baskı, Ankara: Pegem Akademi.

Bompa, T. O. ve Haff, G. G. (2015). Dönemleme: Antrenman Kuramı ve Yöntemi. (Çev. Tanju Bağırgan), Beşinci Basım, Ankara: Spor Yayınevi ve Kitabevi.

Çalgın, E. R. (2003). Niğde ilinde görev yapmakta olan beden eğitimi öğretmenlerinin mevcut durumlarının değerlendirilmesi ve meslek sorunlarının tespiti. Yayımlanmamış yükseklisans tezi, Niğde: Niğde Üniversitesi.

Davison, B. (1998). Creative Physical Activities And Equipment. USA: Human Kinetics, Champaign, IL.

Demirhan, G. (2006). Spor Eğitiminin Temelleri. Ankara: Bağırgan Yayımevi.

Demirhan, G., Bulca, Y., Altay, F., Şahin, R., ve diğerleri. (2008). Beden eğitimi öğretim programları ve programların yürütülmesine ilişkin paydaş görüşlerinin karşılaştııılması. Spor Bilimleri Dergisi, 19(3), 157-180.

Demirhan, G., Bulca, Y., Saçlı, F. ve Kangalgil, M. (2014). Beden Eğitimi Öğretmenlerinin Uygulamada Karşılaştkları Sorunlar ve Çözüm Önerileri. Hacettepe Üniversitesi Eğitim Fakültesi Dergisi, 29(2), 57-68.

Erdemli, A. (2008). Spor Yapan İnsan. Birinci Baskı, i̇stanbul: e-Yayınları.

Ertürk, S. (1986). Eğitimde Program Geliştirme. 5. Baskı, Ankara: METEKSAN Lmt. Şti. 
Fitzpatrick, J. L., Sanders, J. R. \& Worthen, B. R. (2004). Program Evaluation: Alternative Approaches and Practical Guidelines. (Third Ed.), Boston: Pearson Education, Inc.

Gallahue, D. L. \& Donnelly, F. C. (2003). Developmental Physical Education for All Children. (4th. Ed.), Champaign, IL: Human Kinetics Gordon, T. (1993). Etkili Öğretmenlik Eğitimi. (Çev. Emel Aksay ve Birsen Özkan), İstanbul: YA-PA.

Gönen, M. ve Uyar Dalkılıç, N. (1998). Çocuk Eğitiminde Drama: Yöntem ve Uygulamalar. Birinci Baskı, İstanbul: Epilson Yayıncılık.

Graham, G., Holt-Hale, S. A., \& Parker, M. (2001). Children Moving: A Reflective Approach to Teaching Physical Education. 5th Ed., USA: Myfield Publishing Company.

Gredler, M. E. (1996). Program Evaluation. USA: A Pearson Education Company, Prentice-Hall, Inc.

Gümüş, H., Saraçlı, S., Karakullukçu, Ö. F., Doğanay, G. ve Kurtipek, S. (2016). Ortaöğretim Öğrencilerinde Fair Play Kavramı. International Journal of Science Culture and Sport, 4 (Special Issue 2), Doi: 10.14486/IntJSCS568.

Henson, K. T. (1995). Curriculum Development For Education Reform. $2^{\text {nd }}$ Ed., New York: An Imprint of Addison Wesley Logman, Inc. Huizinga, J. (1955-1995). Homo Ludens: Oyunun Toplumsal İşlevi Üzerine Bir Deneme. (Çev. Mehmet Ali Kılıçbay), Birinci Basım, İstanbul: Ayrınt Yayınları.

Hürriyet Gazetesi (2012), Türkiye'de Olimpiyat Kültürü Yok, http://www.hurriyet.com.tr/, Erişim Tarihi: 25.02.2018.

Jewett, A. E., Bain, L. L. \& Ennis, C. D. (1995). The Curriculum Process in Physical Education. USA: Wm. C. Brown Communications, Inc.

Kayışoğlu, N. B., Altinkök, M., Temel, C. \& Yüksel, Y. (2015). Investigation of secondary school students' Physical Education sportsmanship behaviours: Karabük sample. International Journal of Social Sciences and Education Research, 1(3), 865-874.

Kokkinos, P. F. \& Fernhall, B. (1999). Physical activity and high density lipoprotein cholesterol levels: what is the relationship? Sports Medicine, 28(5):307-314.

McCaslin, N. (2016). Yaratıcı Drama: Sınıf İçinde ve Dışında. (Çev. Ed. Pınar Özdemir Şimşek), Sekizinci Baskı, Ankara: Nobel Akademik Yayıncılık.

McNeil, J. (1996). Curriculum: A Comprehensive Introduction. $5^{\text {th }}$ Ed., New York: HarperCollins Publishers, Inc.

MEB, (2009). Ortaöğretim Beden Eğitimi Dersi Öğretim Programı (9-12. Sınıflar). Millî Eğitim Bakanlı̆̆ Ortaöğretim Genel Müdürlüğü, Bursa.

Miller, T. D., Balady, G. J. \& Fletcher, G. F. (1997). Exercise and its role in the prevention and rehabilitation of cardiovascular disease. Ann Behavior Medicine, 19(3), 220-229.

Montessori, M. (1975). Çocuk Eğitimi: Montessori Yöntemi. (Çev. Güler Yücel), İstanbul: Sander Yayınları.

Morrison, G. R., Ross, S. M., Kalman, H. K. \& Kemp, J. E (2011). Designing, Effective and Instruction. 6th Ed., USA: John Willey \& Sons, Inc. Oliva, P. F. (2001). Developing The Curriculum. 15th ed., Boston: Scott, Foresman and Company.

Ornstein, A. C. \& Hunkins, F. P. (1998). Curriculum: Foundations, Principles, and Issues. 3th Ed., USA: Allyn and Bacon, A Viacom Company, Inc.

Özcan, G. ve Mirzeoğlu, A. D. (2014). Beden eğitimi dersi öğretim programına ilişkin öğrenci, veli ve beden eğitimi öğretmenlerinin görüşleri. Amasya Üniversitesi Eğitim Fakültesi Dergisi, 3(1), 98-121.

Özçelik, D. A. (1987). Eğitim Programları ve Öğretim (Genel Öğretim Yöntemi). Ankara: ÖsYM Eğitim Yayınları, No. 8.

Özkan, M. ve Arslantaş, İ. (2013). Etkili öğretmen özellikleri üzerine sıralama yöntemiyle bir ölçekleme çalışması. Trakya Üniversitesi Sosyal Bilimler Dergisi, 15(1), 311-330.

Pehlivan, Z. (2012). Beden Eğitimi Derslerinde İstenmeyen Öğrenci Davranışları, Öğretmenlerin Sözlü Dönüt Biçimi ve Dönüt Biçiminin Öğrenci Başarı Güdüsüne Etkisi. Spor Bilimleri Dergisi, 23 (3), 144-158.

Pehlivan, Z. (2013). Okullararası Spor Yarışmalarına Katılanların Sporu Bırakma ve Devam Etme Nedenleri. Spor Bilimleri Dergisi. 24 (3), 209-225.

Popham, W. J. (1193). Educational Evaluation. Third Edition, Boston: Allyn and Bacon, A Division of Simon \& Schuster, Inc.

Robbins, L. B., Gretebeck, K.A., Kazanis, A. S. \& Pender, N. J. (2006). Girls on the move program to increase physical activity participation. Nurs Res. 55(3), 206-16.

Sağık ve Milli Eğitim Bakanlığı (2017). Beden Eğitimi Ve Spor Öğretmenleri İçin Sağlıkla İlgili Fiziksel Uygunluk Karnesi Uygulama Rehberi. http://okulsagligi.meb.gov.tr/meb, Erişim tarihi: 10.03.2018.

Sallis, J.F., Patrick, K., Frank, E., Pratt, M., Wechsler, H. \& Galuska, D. A. (2000). Interventions in health care settings to promote healthfule eating and physical activity in children and adolescents. Preventive Medicine, 31,112-120.

Saylor, J. G., Alexander, W. M. \& Lewis, A. J. (1981). Curriculum Planning for Better Teaching and Learning, 4th Ed, USA: Holt, Rinehart and Winston, Inc.

Siedentop, D. \& Tannehill, D. (2000). Developing Teaching Skills in Physical Education. California: Mayfield Publishing Company.

Stillwel, J. L. \& Willgoose, C. E. (1997). The Physical Education Curriculum. Boston: Allyn and Bacon.

Şeker, H., (2014). Program Değerlendirme, İçinde: Eğitimde Program Geliştirme: Kavramlar, Yaklaşımlar, Ed. Hasan Şeker. 3. Baskı, Ankara: Anı Yayıncılık. 
Taşmektepligil, Y., Yılmaz, Ç., İmamoğlu, O. ve Kılcıgil, E. (2006). İlköğretim okullarında beden eğitimi ders hedeflerinin gerçekleşme düzeyi. SPORMETRE Beden Eğitimi ve Spor Bilimleri Dergisi, IV(4), 139-147.

Topbaş, E. (2013). Montessori Yöntemiyle Çocuk Eğitimi. Üçüncü Baskı, Ankara: Panama Yayıncılık.

Tyler, R. W. (1967). Basic Principles of Curriculum and Instruction. 26th. Ed, The Universty of Chicago, Chicago-Illinois.

Varış, F. (1988). Eğitimde Program Geliştirme "Teori ve Teknikler”. Dördüncü Baskı, Ankara: Ankara Üniversitesi Basımevi.

Yıldıran, İ. (2011). Fair play: Etimolojik, semantik ve tarihsel bir bakış. Gazi Beden Eğitimi ve Spor Bilimleri Dergisi, XVI (4), 3-18.

Yüksel, İ. ve Sağlam, M. (2014). Eğitimde Program Değerlendirme. 2. Baskı, Ankara: Pegem Akademi. 